\title{
The attitude of Polish youth towards migrants, and educational process planning in geography teaching Using the example of selected groups of students from Poznań and Warsaw
}

\begin{abstract}
The political destabilization in the Middle East has caused such a significant wave of migration to European countries, that the situation has evolved into a migration crisis. Research on the awareness and opinions on mass migration conducted among a selected group of Polish youth show how differentiated attitudes are - from moderately positive to extremely negative. At the same time, almost everyone signaled that schools' engagement in providing students with solid knowledge on migration was insufficient. In this context, this paper discusses the importance of taking account of students' opinions in the planning of educational processes. If schools are to influence the attitudes of the young, they should create a space for dialogue and for students to express their opinions and values. Such activities, together with solid knowledge, will allow educational and pedagogical objectives to be reached.
\end{abstract}

Keywords

Migration crisis $\bullet$ migrants $\cdot$ refugees $\cdot$ youth attitude $\bullet$ educational process - geography education

(c) University of Warsaw - Faculty of Geography and Regional Studies

Introduction

In today's academic discourse, attitudes towards representatives of other cultural groups are an essential and topical research subject for psychologists, sociologists, and teachers, as well as experts from such fields as cultural studies, ethnography, and geography. In recent years, these issues have gained special importance, first and foremost due to the migration crisis that followed the mass influx of migrants to Europe.

The notion of mass migrations seems to be critical, not only because of the scale and relevance of the problem, but also due to the need to prepare Polish society's youngest generations for living in a new reality with unavoidable, significant cultural differences. Moreover, these issues are important from the point of view of the educational process, both in high schools and at universities, through which students have to gain something more than just knowledge or skills. The integral part of this process is forming attitudes towards various aspects of reality, including the phenomenon of multiculturalism. The main purpose of this paper is to discuss the importance of students' attitudes and opinions in planning the educational process, including the teaching of geography. An important element of these reflections is to present the results of research conducted at the turn of 2015 and 2016 (the highest point in the European migration crisis) among a selected group of students from Poznań and Warsaw. The responses received from the students showed how strong, or even extreme, the emotions and feelings were among young people in their reaction to this phenomenon.

\section{Social and cultural context}

Unlike most the Western European countries, Poland is characterized by its society's relatively homogenous ethnic and religious structure. Ethnic minorities amount to less than

\author{
Alina Awramiuk-Godun $\mathbb{C}^{1}$, \\ Janusz Górny $\mathbb{1}^{2}$ \\ 'Faculty of Geography and Regional Studies, \\ University of Warsaw, Poland \\ e-mail: alina.awramiuk@uw.edu.pl \\ ${ }^{2}$ Faculty of Socio-Economic Geography and \\ Spatial Management, Adam Mickiewicz \\ University in Poznań, Poland \\ e-mail: janusz@amu.edu.pl \\ Received: 16 June 2019 \\ Accepted: 24 March 2020
}

$3.8 \%$ of the country's population (i.e., $1,467,000$ persons) (Struktura narodowo-etniczna 2015). ${ }^{1}$ Here we are primarily referring to representatives of ethnic groups who have been resident in the historical cultural borderlands for several generations (e.g., Podlasie, Silesia, Kashubia). From the legal point of view, there are nine recognized national minorities in Poland: Lithuanians, Belarusians, Ukrainians, Germans, Slovaks, Czechs, Russians, Armenians, and Jews. At the same time, there are four recognized ethnic minorities: Karaites, Roma, Tatars, and Lemkos. Furthermore, Kashubians are considered to be a separate cultural community, who use a regional language (Ustawa o mniejszościach narodowych 2005). All such minorities in Poland have the guaranteed right to use their native language in private and in public (including in public administration offices), to be able to learn their native language in schools, and to preserve and develop their cultural identity.

In recent years, Poland has observed a progressive growth in the number of economic migrants, primarily from Eastern European countries such as Ukraine, Belarus, and Moldova. Due to the nature of their migration, such incomers settle mainly in the larger agglomerations and key economic areas, including Warsaw, Lublin, and Wrocław; and seek employment in construction, agriculture, and services, among other options. In 2018, according to official data provided by the Polish Office for Foreigners (Urząd do Spraw Cudzoziemców 2018), there were 366,400 legal migrants in Poland, of whom, Ukrainians constituted the largest group with $47.7 \%$. As for refugees, this status was assigned to 1,364 persons, subsidiary protection was granted

\footnotetext{
1 This data is derived from the General Census conducted in 2011, and concerns persons declaring a non-Polish national or ethnic identity, including complex, double identity, i.e., Polish and non-Polish simultaneously.
} 
to 2,029 persons, and 288 persons were given a tolerated stay permit. ${ }^{2}$ International protection is mostly awarded to Ukrainians and Russians in Poland; however, during previous periods (e.g., in 2003 and 2010), the most numerous group were Chechens. Compared to figures for Western European countries, in Poland, the number of persons who receive refugee status as a proportion of those who apply is negligible. ${ }^{3}$

The mass migration seen in Western European countries in the last few years is on a scale not observed since World War II. This migration was caused, primarily, by the political destabilization of the Middle East due to the civil conflict in Syria, and the war with the so-called Islamic State of Syria and Iraq (ISIS). According to estimates, more than one million refugees and economic migrants arrived in Europe in 2015. The very phenomenon of mass migration, along with the resulting migration crisis and its potential consequences, provoked a genuine and heated debate among European citizens. Those discussions have been especially visible in the various media, and even more so after the terrorist attacks that took place in Belgium, France, and Germany. ${ }^{4}$ In the public debate, the foreground space has been occupied by the risks and possible threats caused by the influx of migrants coming to European countries, including Poland. It is not surprising that this evokes intense fear and anxiety among the general population.

Research on attitudes towards the "other": chosen directions and challenges

Due to the vast corpus available, and the thematic diversity of the research findings, only a selection of sources was considered, based on their importance to the analysis in this work, i.e., studying the attitudes of Poles and other Europeans, especially children and youth, towards migrants.

The significance of this subject is further confirmed by the establishment of interdisciplinary research teams at academic institutions (e.g., universities), who deal with the analysis of various expressions, especially negative ones such as stereotypes and prejudices, toward other cultural and social groups resulting from society's perceptions of these groups. Among the academic establishments specializing in this subject, an important role is played by the Centre for Research on Prejudice (CRP). ${ }^{5}$ One of its activities has been to conduct the Polish Prejudice Survey, a national, multidimensional survey of attitudes towards national minorities and ethnic groups. From 2015 to 2017 , during the culmination of the migration crisis, the CRP conducted a series of studies on the attitudes of Poles towards migrants and refugees (i.a., Bieńkowski \& Świderska 2017, Świderska et al. 2016). These works showed a diversity and change in attitudes, as well as revealing the key factors contributing to the attitudes' formation. From the educational point of view, the most interesting conclusions are given by a study on Poles' associations with the term, refugee (Kropiński \& Hansen 2016). The same organization conducted research on the attitudes of the local community towards refugees of Chechen origin who were residing in the Łomża Refugee Centre (Bilewicz et al. 2012).

\footnotetext{
${ }^{2}$ This data was taken from the migracje.gov.pl (2018) portal.

${ }^{3}$ Every year, the number of applications for refugee status in Poland oscillates between several and twenty thousand. Yet, only a handful of applications are approved. In 2017, there were more than 5,000 applications filed, while only 520 persons were granted international protection, and 227 were given a tolerated stay permit (Urząd do Spraw Cudzoziemców, 2018).

${ }^{4} \mathrm{~A}$ series of terrorist attacks took place in Europe, in Paris (November 2015), Brussels (March 2016), Nice and Munich (July 2016), and Berlin (December 2016).

${ }^{5}$ The Center for Research on Prejudice is an interdisciplinary unit, under the Psychology Department of the University of Warsaw, that unites social psychologists and sociologists dealing with the issues of stereotypes, prejudices, racism, discrimination, and other notions from the domain of intergroup relations.
}

On the European scale, these issues are explored within the scope of the European Social Survey (ESS). ${ }^{6}$ The ESS is a comprehensive and rich source of data on the attitudes, opinions, and behavior models of different European societies. The data is used in comparative and cross-sectional studies on the situation in the whole of Europe (Gorodzeisky \& Semyonov 2018, Laurence \& Bently 2018, Attitudes towards Immigration and their Antecedents 2016, Paas \& Halapuu 2012), as well as being a basis for national and regional reports (Andrejuk 2015).

Public opinion polls are also a major source of information on social attitudes. In many countries, including Poland, there has been an ongoing monitoring of citizens' opinions on migrants since the very beginning of the migration crisis. Such polls have been conducted by private companies or foundations specializing in surveys on representative samples of the general population. Since 2015, the Public Opinion Research Centre Foundation (CBOS) has been studying the attitudes of Poles towards the welcoming of refugees, by asking them the following question: "According to you, should Poland be welcoming refugees from the countries involved in military conflicts?" (Polacy wobec problemu uchodźstwa 2015). The results of the 2015 poll show that over several months, between May and December 2015, Poles' opinions on this matter changed drastically. A strong decline, from $72 \%$ to $56 \%$, was seen in the number of people stating the need to welcome refugees, while the opposite opinion grew from $21 \%$ to $40 \%$. Moreover, the percentage of those with no opinion on the matter decreased. The highest level of Poles' reluctance to take in refugees, 61\%, was observed in April 2016 (Stosunek Polaków do przyjmowania uchodźców 2016). A poll conducted in June 2018 confirmed the overall trend: some $60 \%$ of those surveyed were against welcoming refugees (Stosunek Polaków i Czechów do przyjmowania uchodźców 2018).

The results of such surveys are often used in planning specific activities that implement the migration policies of states; for example, they are aimed at the social integration of migrants, or at limiting discriminatory behavior through educational programs. Thus, information on how young people perceive the phenomenon of migration and its consequences, as well as their attitude towards representatives of other cultural groups, is essential. Such knowledge should constitute one of the elements of educational planning, including the preparation of curricula and educational materials.

\section{Research on the attitudes of youth}

In Poland, studies on the attitudes of children and youth towards other cultural groups (national, ethnic, religious) are conducted relatively rarely compared to those on the general population. When they are done, they are carried out locally due to the specificity of the Polish social and cultural context. Moreover, such surveys are not usually commissioned by the institutions in charge of the education system, i.e., in Poland, the Ministry of National Education.

Most of the available studies focus on analyzing declared attitudes towards similar nations or ethnic groups (e.g., Poland's neighbors: Germans, Russians, Czechs); groups, who in the public's opinion, are significantly disadvantaged (e.g., Roma, Russians); or favored groups (Americans, Italians, French, Czechs); as wells as such specific cases as Jews and Roma (Karolczak-Biernacka 1995, eds. Weigl \& Maliszkiewicz 1998, as cited in Górak-Sosnowska 2011). Some of the surveys are conducted among students in regions with strong ethnic and religious diversity, for example, Podlasie. Such studies mostly focus on the attitudes

\footnotetext{
${ }^{6}$ The European Social Survey is an international research project initiated in 2001 by the Experts Board of the European Science Foundation. Its main aim is to observe social change taking place in Europe: attitudes towards key challenges, and changes in value systems and behavior.
} 
towards their own minority group (Jasińska-Kania \& Staszyńska 2009; Karolczak-Biernacka 1995).

In the face of the migration crisis there is a growing interest in assessing the attitudes of youth towards migrants, including refugees. In Poland, there have recently been several studies on these issues, amongst others, (ed.) Balicki \& Necel (2017), Mróz \& Ziółkowska-Weiss (2017), and Awramiuk-Godun \& Górny (2016). In Europe, similar research has been conducted in such countries as Sweden (ed. Hellström 2017) and Scotland (Young people's Attitude to Immigration 2017). In the case of areas with significant proportions of migrants in the society, the studies have highlighted the importance of cross-group contact and its nature (e.g., close relationships, friendship, etc.), as well as its impact on the behavior and attitudes of young people. However, Polish students, unlike their peers from Western Europe, have fewer chances for direct contact with migrants, including refugees, who come from outside the European cultural space (e.g., from the Middle East or North Africa). Their opinions, therefore, are to a large extent a consequence of the narratives present in the media and on social networks. They are also formed by the young people's milieu, i.e., their families, peers, and schools. Thus, the role of the school in forming attitudes and preparing students for life in a culturally diverse society seems to be of high importance. A review of the available studies has shown that such a perspective is rarely taken by researchers in Poland.

\section{Attitudes of Polish youth towards migrants}

The primary objective of the current survey, which was conducted among high school and university students, was to determine the attitudes of youth towards the large migration wave that swept into Europe in 2015-2016, and its consequences, including the migration crisis.

The survey was carried out in October and November $2015^{7}$ on a sample of 230 persons (with $61.3 \%$ of the participants being female and $38.7 \%$ being male). Forty of the respondents were students of the Geography Faculty at the Warsaw University, 83 were students of a junior high school in Poznań, and 107 were students of a high school in the same city.

The authors of the study considered it their main goal to let young people share their opinions on the mass migration phenomenon, as well as on the role of the environment, especially schools, in the formation of those opinions; thus, qualitative methods were chosen. The research instrument was a questionnaire, which consisted mainly of open questions. ${ }^{8}$ In the context of planning the educational process, it seems to be more important to know what the students really think about the matter, rather than focusing on their abstract views; the collected answers are often hard to categorize, and it is difficult to present the results in a clear percentage-based structure, which was not the aim of the research in any case. Therefore, the current analysis shows a selection of the students' responses that best represent the diversity of their opinions. Regrettably, many of them reflected the general negative attitude and resentment towards immigrants (refugees) observed in Polish society at that time. At the same time, no clear differences in attitudes between high school and university students were observed. Furthermore, the presence of numerous stereotypical and false opinions in the responses of both of the groups under study may indicate the small role of formal

${ }^{7}$ Some of the responses were given before the terrorist attacks in Paris on 13 November 2015 , some only after.

${ }^{8}$ The questionnaire included seven questions. The first two dealt with knowledge on the current mass migration to Europe. The students were asked about the origins of the migrants and the reasons behind them moving to Europe. The following questions concerned the sources of information on mass migration. The next-to-last question was about the attitude of young people towards welcoming migrants (refugees) in Poland and the potential consequences of immigrants becoming residents. The last question concerned the role of schools in the forming of their opinions. school and academic education (including geography teaching) in shaping the knowledge and awareness of young people.

Students most often indicated a political conflict, or a generally unstable situation in the migrants' country of origin as being among the reasons for mass migration: "because of war, famine, unrest, lack of resources," "they're searching for a safe place to live in," "they're fleeing from war and terror," or "from religious persecution." A substantial group of respondents mentioned economic factors as being equal to war, or even as being the most fundamental factor. Some answers claimed that migrants come to Europe to improve their material standing, or get welfare support, in which case, the students clearly stated that these were not refugees but immigrants.

Several of the responses included the cultural aspect, framed as the intention to spread the influence of Islamic culture, for example: "they're spreading Islam, often brutally," and "they want to conquer territories to impose the dominance of their religion." Some mentioned the destabilization of the situation in Europe through terrorist attacks: "they're coming to Europe to kill people."

When asked to list their sources of knowledge on the issue of mass migration, the students typically mentioned television and the internet, as well as (but less frequently) parents and other family members, which means that these subjects are discussed in the students' homes. A group of respondents also mentioned school, friends, and acquaintances. The least represented sources among the responses were printed media, and radio.

Following on this idea came the next question, which was related to the role of schools in transmitting knowledge about migration. The students were asked to list the subjects in which the issue of mass migration were touched upon. The junior high school students mentioned safety education lessons, geography, history, and civics; as well as, in some cases, Polish and English language lessons, and religion. In only one of the six classes surveyed, was there a mention of form time (homeroom), which would seem to be the best space to influence the attitudes of the students. Respondents from the senior high school singled out geography lessons and civics, as well as a special lesson on the subject organized by the school. Some of the students underlined that there was not enough discussion during the lessons in which the issue of migration was touched upon, and that such discussions should take place during history and civics lessons.

The students were also asked what their decision would have been, had they been members of the Polish Government. Would they welcome immigrants or not? What changes might happen in Poland due to the mass influx of people of a different nationality, religion, and culture?

Numerous students said they would welcome migrants, especially refugees, because of their difficult circumstances: "we can't abandon people in need," "these people need help," "I sympathize with these people, and I would like to be able to count on the reciprocation of help in the future."

However, most of the respondents who declared their readiness to welcome migrants also laid down certain terms. These conditions often had to do with limiting the number of arriving migrants, and verification of their details and an identity check: "only those who pass certain psychological tests," "upon full verification," "accept only those fleeing from wars, families with children, and not Islamic fanatics," "only women, children, elderly people, [and] disabled persons," "women and children only, their men should go back and fight for their country."

A significant number of high school students, and the majority of university students were strongly against welcoming migrants, justifying their position using specific reasons, and the potential threats that may arise as a consequence. The most popular responses included: 
- the difficult economic conditions in Poland: "we can't afford this," "our authorities have to pay attention to Poland's internal problems first, e.g., supporting poor families," "I don't want our money to be directed to help refugees who would then live better and easier than some hard-working Poles;"

- the overly strong cultural differences that may cause tensions and religious conflict: "welcoming migrants may result in (...) riots and fights between the migrants and the Poles," "Poland is not ready, mentally, because we are afraid of things foreign and different;"

- the fear of terrorist attacks: "the risk of terrorist attacks is too high, besides those migrants are men ready for combat, so why aren't they fighting in their country and why are they fleeing and leaving women and children behind?" "we should not welcome [the migrants because] currently there is no system in place to distinguish between refugees and migrants, or terrorists;"

- the risk of Polish culture being extinguished, caused by the incoming population's pursuit of dominance and the imposition of their cultural patterns: "I'd be afraid that they wouldn't be a minority but would start demanding equal rights in Poland," "in a dozen years (...) [unfamiliarity with] the Koran will result in being executed in the middle of the street in Warsaw," or that "Polish society will be divided, a 'foreign' culture and religion will expand, which may result in its attempts to dominate in Poland," as well as "many people, and I am not an exception, are afraid that the immigrants will want to rule, introduce their ways of life."

Equating migration with the danger of terrorism and, thereby, identifying migrants (refugees) as Muslims and terrorists was quite common in the students' responses. A situation in which all migrants are considered potential terrorists is disturbing, as it can cause a surge in conflict about cultural backgrounds, and rise in aggression towards people of different appearance, religion, or culture.

Some of the students acknowledged, though, that their attitude towards migrants had changed: "after the recent events in Paris, I am more skeptical than before." Some note that "the risk of terrorism can never be avoided completely, it exists even outside the scope of the refugee issue."

Responses warning of the risk of a decline in Polish culture may indicate the students' low level of awareness of regional and national identity. This could be a potential area for educational and pedagogic intervention within the scope of regional and patriotic education. Some responses suggested that the problem lies not only on the side of the incomers but also on the side of Polish society, which is characterized by "xenophobia and a low level of tolerance, [while] the conflicts are caused by a lack of awareness of intercultural differences between Europeans and the arriving population." There were also voices of discouragement: "I wish I could say that the influx of representatives of a different culture would cause a rise in our tolerance and openness towards diversity, yet, hearing the opinions of people around me I begin to doubt whether this is possible." One of the respondents assumed that the presence of migrants in the country "would not change much, as they will be oppressed and cast out by the Poles."

Finally, it is worth mentioning that several of the responses suggested that a small number of migrants would not, in fact, affect the life of Polish society in any way: "they will be too few to make any significant impact." Some of the students noted possible, positive changes as a result of welcoming migrants, for example, a rise in levels of tolerance: "The Poles will have a chance to see for themselves that other nations, religions, and cultures are not bad or evil, that they can contribute a lot to our life," "I hope that Poland would open up more," "multicultural societies are really a good thing."

The students' responses indicate that there was hardly anyone among them who would be indifferent towards the subject of mass migration. The survey participants were eager to share their opinions in all honesty. The examples given above prove how wide the variety of responses and, therefore, the attitudes of the students were: from moderately positive to extremely negative. Due to Polish society's strongly monolithic, national and religious identity, as well as their lack of direct contact with immigrants, the fears and concerns regarding foreign cultures seem to be understandable to a certain extent, especially in the context of events taking place in other countries, i.e., social conflicts along ethnic lines, and suicide and other types of terrorist attacks. It is also largely based on an information policy that focuses public discourse around the issues of the potential threats of welcoming refugees to Poland. Quite often, the media (especially those who are pro-government) present the Polish authorities' negative stance towards EU migration policy as being justified by citizens' safety concerns. Many of the students' responses reflected this logic, and clearly point to contexts in which they may have encountered such frames (e.g., in the speeches and comments of certain politicians). Thus, their opinion is mostly formed by the media's narrative and discussions taking place within their local communities (in their families, among peers, and at school), as well as online.

Attitudes and opinions of students and educational process planning

Migration is a global, social, economic, and cultural phenomenon with, at times, dramatic local consequences. According to forecasts made by numerous researchers, migration will intensify, particularly in relation to climate change (IPCC 2014, Abel et al. 2019). In this context, it is crucial for students to be aware of the ongoing processes, and to acquire sound knowledge as to the causes and effects of migration, including the dynamics of the relations between migrants and local communities. Therefore, one of the important tasks of school education is to shape attitudes of openness and empathy towards migrants, especially refugees, who are often driven out of their countries by wars, conflicts, or persecution.

Referring to the attitudes and feelings of students can be of great help in the pedagogical process, especially if such emotiontriggering issues as the current mass migration to Europe are discussed during lessons. In the view of numerous teachers and psychologists, creating a space for dialogue constitutes a crucial element in the formation of students' attitudes. This should be based on two components: solid knowledge, and the chance for all parties to express their opinions and attitudes (Koszewska 2001, Rozmawiamy o uchodźcach 2016).

Schools should provide comprehensive and evidencebased knowledge, in which neutrality is maintained, since such neutrality is required to gain students' trust. Usually, the school textbooks cannot keep up with the latest information concerning ongoing dynamic, social, economic, and political processes, such as mass migration, therefore, teachers should attempt to gather verified information themselves. Among examples of reliable information sources one should mention such information portals as Refugee Week (refugeeweek.org.uk), or the Polish site, uchodzcy.info, which were created with the goal of raising social awareness about the topic of migrants in Europe by means of spreading solid data and countering stereotypes. They allow the false views, stereotypes, and lies about refugees that appear in students' responses (e.g., "refugees are terrorists," or "they are a threat to our culture") to be confronted with facts and evidence. 
Another source of information can be found in the statistical data published by the state agencies in charge of immigrants; in Poland this is the Office for Foreigners.

Using solid knowledge and trustworthy sources will allow prejudices to be confronted with reality, and false convictions to be corrected. This is all the more important when students' answers and opinions show signs of resentment, or even aggression and contempt, towards migrants. Whatever their personal views, teachers encountering such opinions among their students should not remain indifferent.

In order for dialog to be possible, all sides and parties, who represent diverse attitudes and convictions, even extreme ones, should have the space to present them. Avoiding challenging subjects or ignoring an interlocutor's views may actually strengthen the convictions one is trying to change (Stephan et al. 2004 as cited in Kropiński \& Hansen 2016). For example, framing refugees as terrorists and criminals might suggest that students are expressing their fears. These should not be ignored, but compared to reliable and evidence-based data that proves that such concerns are not supported by facts.

Researchers dealing with the notion of attitudes towards different cultural groups also emphasize that, while discussing the migration issue during school lessons, it is important to highlight the feelings and emotions experienced by refugees (e.g., fear, anxiety, helplessness), and the difficult circumstances they have found themselves in due to the turmoil in their home country. Studies have shown that those who try to understand and to realize how difficult the migrants' situation is, are less likely to display negative attitudes, or apply stereotypes or objectification to migrants (Kropiński \& Hansen 2016). Therefore, while preparing a geography lesson on the topic of migration, it is highly advisable to use strategies and methods that promote the students' active involvement (e.g., discussion, didactic games, drama, improvisation). Through emotional engagement (e.g., by playing the role of an immigrant) a young person can better understand the situation and the challenges faced by these groups. The "Let's talk about refugees" educational project by the Centre for Citizenship Education (Centrum Edukacji Obywatelskiej, CEO) can be a source of valuable educational materials and methodology for tackling the issue of modern migrations to Europe. Teachers can find support on both content (such as a list of key and proven facts) and methods (lessons plans) there.

\section{Conclusion}

The study of contemporary socio-economic and political processes and phenomena (such as the migration crisis) and the role of educational institutions in overcoming their negative effects is a serious problem and a social challenge, not only for Poland but, for other European countries as well. It requires that comprehensive, interdisciplinary research (including forecasts) be conducted, for example, on the phenomenon of multiculturalism, involving representatives of a range of disciplines: psychologists, sociologists, educators, cultural scholars, as well as geographers (including geography teachers and teachers in general).

When the world is shaken by events that may have social, political, and economic consequences, and which can have a significant impact on the situation in any country, we should not neglect such developments in the educational process. The migration crisis that has taken place in Europe in recent years is an example of such a phenomenon, the causes, course, and consequences of which have been felt in many regions of Europe, Asia, and Africa. It therefore has a global dimension. One of the tasks of schools is to form young minds in a way that allows them to comprehend the complicated social and economic processes taking place in the modern world, along with their complexity, interdependence, and outcomes. Educational processes should help students understand the dynamically changing world and enable them to find their own place within it. The responses of high school and university students gathered within the scope of this research allow teachers to discover students' opinions on these matters, as well as face the students' awareness levels, which is, quite often, too low, and consists of sets of stereotypes ("in France, there are more dark-skinned people now than white people," "we will not even notice how one day there will be more mosques in Poland than churches"). Conducting such a survey among one's students may result in a more conscious preparation of lessons, which will, in their turn, better prepare students for the changes happening both locally and globally. In order to achieve the intended pedagogical effect, a teacher who is preparing educational processes should be ready to engage in a dialogue with students who express extreme or stereotypical views. This, however, requires solid knowledge and perfect planning.

\section{ORCID}

Alina Awramiuk-Godun (1D https://orcid.org/0000-0001-6996-0921 Janusz Górny (1D https://orcid.org/0000-0003-3421-5176

\section{References}

Abel, JG, Brottrager, M, Crespo Cuaresma, J \& Muttarak R 2019, 'Climate, conflict and forced migration', Global Environmental Change, vol. 54, pp. 239-249.

Andrejuk, K 2015, Postawy wobec imigrantów w świetle Europejskiego Sondażu Społecznego 2014-2015, Polska na tle Europy, [Attitudes towards immigrants in the light of the European Social Survey 2014-2015] working paper no. 2/2015, Institut of Philosophy and Sociology, Polish Academy of Science, Warsaw. Available form: <http://www.ifispan.pl/ raport-o-wynikach-europejskiego-sondazu-spolecznego/>. [12 December 2018]

Awramiuk-Godun, A \& Górny, J 2016, 'Treści nauczania geografii a kształtowanie postaw młodzieży wobec masowych migracji' [Teaching contents of geography versus formation of young people's attitude to mass migrations], Prace Komisji Edukacji Geograficznej Polskiego Towarzystwa Geograficznego, vol. 6, pp. 125-141

Attitudes towards Immigration and their Antecedents: Topline Results of Round 7 of European Social Survey, 2016, ESS Topline Results Series, Report. Available form: <https://www.
europeansocialsurvey.org/docs/findings/ESS7 toplines issue_7_immigration.pdf>. [12 December 2018]

Balicki, J \& Necel, W (eds) 2017, Kryzys migracyjny w Europie. Wyzwania etyczne, społeczno-kulturowe $i$ etniczne [Migration crisis in Europe. Ethical, socio-cultural and ethnic challenges] Wydawnictwo Naukowe Uniwersytetu Kardynała Stefana Wyszyńskiego, Warszawa

Bieńkowski, M \& Świderska, A 2017, Postawy wobec imigrantów i uchodźców. Panel badań społecznych, [Attitudes towards immigrants and refugees. Social research panel] Centrum Badań nad Uprzedzeniami, Warszawa. Available form: <http://cbu.psychologia.pl/pl/publikacje/raporty-z-badan>. [20 November 2018]

Bilewicz, M, Górska, P, Jaworska, M, Olechowski, M \& Witkowska, M 2012, Stosunek do uchodźców. Możliwości zmian [Attitude towards refugees. Possibilities of changes], Centrum Badań nad Uprzedzeniami, Warszawa. Available form: $\quad<$ http://cbu.psychologia.pl/pl/publikacje/raporty-zbadan>. [20 November 2018] 
Gorodzeisky, A \& Semyonov, M 2018, 'Competitive Threat and Temporal Change in Anti-Immigrant Sentiment: Insights from a Hierarchical Age-Period-Cohort Model', Social Science Research, vol. 73, pp. 31-44

Górak-Sosnowska, K 2011, 'Edukacja międzykulturowa a postawy wobec „Innych”', [Intercultural education and attitudes towards „Others”] Kwartalnik Kolegium SpołecznoEkonomicznego Studia i Prace SGH, vol. 4, pp. 51-66

Hellström, A (ed.) 2017, Attitudes Towards Immigrants among Youth in Sweden, Malmö Institute for Studies of Migration, Diversity and Welfare (MIM), Malmö University. Available from: <https://www.mah.se/upload/Forskningscentrum/MIM/ Publications/17.4\%20Beint\%20Magnus\%20Aamodt\%20 Bentsen.pdf>. [20 November 2018]

IPCC, 2014, Climate Change 2014: Synthesis Report. Impact, Adaptation, and Vulnerability. Contribution of Working Groups I, II and III to the Fifth Assessment Report of the Intergovernmental Panel on Climate Change. Available from: <https://www.ipcc.ch/report/ar5/wg2>. [15 January 2020]

Jackowski, A, Bilska-Wodecka, E \& Sołjan, I 2014, '80 lat minęło... XIV Kongres Międzynarodowej Unii Geograficznej w Warszawie, 23-31.08.1934' [80 years have passed... XIV Congress of the International Geographical Union in Warsaw] Przegląd Geograficzny, vol. 86, nr 1, pp.115-130

Jasińska-Kania, M \& Staszyńska, K.M 2009, Diagnoza postaw młodzieży województwa podlaskiego wobec odmienności kulturowych, [Diagnosis of the youth attitudes of the podlaskie voivodeship towards cultural differences] Białystok

Karolczak-Biernacka, B 1995, 'Postawy młodzieży wobec mniejszości' [Attitudes of young people towards minorities] in: Edukacja międzykulturowa. W kręgu potrzeb, oczekiwań $i$ stereotypów [Intercultural education. In the circle of needs, expectations and stereotypes] ed. J Nikitorowicz, Trans Humana, Białystok, pp. 271-272

Kropiński, M \& Hansen, K 2016, Jakie skojarzenia ze słowem "uchodźca" mają Polacy?, [What associations with the word „refugee” have Poles?] Centrum Badań nad Uprzedzeniami, Warszawa. Available form: <http://cbu.psychologia.pl/pl/ publikacje/raporty-z-badan>. [20 November 2018]

Koszewska, K (ed.) 2001, Zrozumieć innych, czyli jak uczyć o uchodźcach [Understanding others, or how to teach about refugees] Centralny Ośrodek Doskonalenia Nauczycieli, Warszawa

Laurence, J \& Bently, L 2018, 'Countervailing contact: Community ethnic diversity, anti-immigrant attitudes and mediating pathways of positive and negative inter-ethnic contact in European societies', Social Science Research, vol. 69, pp. 83-110

Migracje.gov.pl 2018, <https://migracje.gov.pl/statystyki>. [10 November 2018]

Mróz, F \& Ziółkowska-Weiss, K 2017, 'Młodzież szkolna i akademicka w Polsce wobec problemu uchodźców' [School and academic youth in Poland towards the problem of refugees] in Kryzys migracyjny w Europie. Wyzwania etyczne, społeczno-kulturowe i etniczne [Migration crisis in Europe. Ethical, socio-cultural and ethnic challenges], eds J Balicki \& W Necel, Wydawnictwo Naukowe Uniwersytetu Kardynała Stefana Wyszyńskiego, Warszawa

Paas, T \& Halapuu, V 2012, 'Attitudes towards immigrants and the integration of ethnically diverse societies', Eastern Journal of European Studies, vol. 3, nr 2, pp. 161-176
Polacy wobec problemu uchodźstwa 2015, [Poles regarding the problem of refugees] Komunikat $z$ badań nr 81/2015, Centrum Badań Opinii Społecznej, Warszawa. Available from: <http://www.cbos.pl>. [20 November 2018]

Rozmawiamy o uchodźcach, Jak rozmawiać...? 2016, [Let's talk about refugees. How to talk...?] Centrum Edukacji Obywatelskiej. Available from: <https://migracje.ceo.org.pl>. [12 December 2018]

Stosunek Polaków do przyjmowania uchodźców 2016, [Attitude of Poles towards welcoming refugees], Komunikat z badań nr 98/2016, Centrum Badań Opinii Społecznej, Warszawa. Available from: <http://www.cbos.pl>. [12 December 2018]

Stosunek Polaków i Czechów do przyjmowania uchodźców 2018, [Attitude of Poles and Czechs towards welcoming refugees] Komunikat z badań nr 87/2018, Centrum Badań Opinii Społecznej, Warszawa. Available from: <https://www. cbos.pl>. [12 December 2018]

Stephan, CW, Renfro, L \& Stephan, WG 2004, 'The evaluation of multicultural education programs: Techniques and metaanalysis' in ed. WG Stephan \& PG Vogt, Education programs for improving intergroup relations: Theory, research and practice, New York: Teachers College Press, pp. 227-242

Struktura narodowo-etniczna, językowa, wyznaniowa ludności Polski, 2015 [The national, ethnic, linguistic and religious structure of the Polish population] GUS, Warszawa. Available from: <https://stat.gov.pl/files/gfx/portalinformacyjny/pl/ defaultaktualnosci/ 5670/22/1/1/struktura_narodowoetniczna.pdf >. [12 December 2018]

Świderska, A, Winiewski, M \& Hansen, K 2016, Przemoc jako rozwiązanie? Napływ uchodźców w opinii Polaków [Violence as a solution? The influx of refugees in the opinion of Poles] Centrum Badań nad Uprzedzeniami, Warszawa. Available from: <http://cbu.psychologia.pl/pl/publikacje/raporty-zbadan>. [20 November 2018]

Ustawa o mniejszościach narodowych $i$ etnicznych oraz o języku regionalnych, 2005, [Act on national and ethnic minorities and on the regional languages]. Available from: $\quad<$ http://prawo.sejm.gov.pl/isap.nsf/DocDetails. xsp?id=WDU20050170141>. [20 November 2018]

Urząd do Spraw Cudzoziemców 2018 [Office for Foreigners] <https://udsc.gov.pl/>. [12 December 2018]

Weigl, B \& Maliszkiewicz, B(eds) 1998, Innito także my. Mniejszości narodowe w Polsce: Białorusini, Cyganie, Litwini, Niemcy, Ukraińcy, Żydzi [Others are also us. National minorities in Poland: Belarusians, Gypsies, Lithuanians, Germans, Ukrainians and Jews] Program edukacji wielokulturowej w szkole podstawowej. [Multicultural education program at primary school] Gdańskie Wydawnictwo Pedagogiczne, Gdańsk

Young People's Attitudes to Immigration: report on findings from the Young People in Scotland Survey 2017, People Communities and Places, Social research, Scottish Government Riaghaltas. Available from: <https://www. gov.scot/Publications/2018/08/ 6022/downloads>. [20 November 2018] 